\title{
Assessment of Poverty by Municipalities in the Context of Population Ageing-The Case of Małopolskie Voivodeship
}

\author{
Małgorzata Ćwiek ${ }^{1, *(D)}$, Katarzyna Maj-Waśniowska ${ }^{2}$ (D) and Katarzyna Stabryła-Chudzio ${ }^{3}$ (D) \\ 1 Department of Statistics, Cracow University of Economics, 31-510 Cracow, Poland \\ 2 Department of Public Finance, Cracow University of Economics, 31-510 Cracow, Poland; \\ katarzyna.maj@uek.krakow.pl \\ 3 Department of Finance and Financial Policy, Cracow University of Economics, 31-510 Cracow, Poland; \\ stabrylk@uek.krakow.pl \\ * Correspondence: malgorzata.cwiek@uek.krakow.pl; Tel.: +48-12-293-52-21
}

Citation: Ćwiek, M.; Maj-Waśniowska, K.; Stabryła-Chudzio, K. Assessment of Poverty by Municipalities in the Context of Population Ageing-The Case of Małopolskie Voivodeship. Sustainability 2021, 13, 2563.

https://doi.org/10.3390/su13052563

Academic Editors:

Filomena Maggino, Leonardo

Salvatore Alaimo, Enrico Di Bella,

Marco Fattore and Matteo Corsi

Received: 8 January 2021

Accepted: 23 February 2021

Published: 27 February 2021

Publisher's Note: MDPI stays neutral with regard to jurisdictional claims in published maps and institutional affiliations.

Copyright: (c) 2021 by the authors. Licensee MDPI, Basel, Switzerland. This article is an open access article distributed under the terms and conditions of the Creative Commons Attribution (CC BY) license (https:/ / creativecommons.org/licenses/by/ $4.0 /)$.

\begin{abstract}
This article undertakes the research problem of the assessment of the significance of poverty as a social challenge for local self-government units, and the differences in the assessment of the incidence of this phenomenon depending on the type of municipality. The authors also analyse the relationships between the ageing of the population and the assessment of the extent of poverty by municipalities. It must be pointed out that the undertaken problem has not been a subject of in-depth analysis thus far. Hence, this article fills the identified research gap in this field. The empirical part is based on the results of our own research, conducted using the Computer-Assisted Web Interview (CAWI) method on a sample of 144 municipalities of the Małopolskie Voivodship (Poland). In order to verify whether there is a relationship between the researched qualitative variables, the chi-square test of independence was used. In order to determine the relationships occurring between the categories of variables characterising the scale of the incidence of poverty and the remaining variables, a correspondence analysis was conducted. The research enabled us to find the issue of poverty to be one of the most important social problems from the point of view of municipalities. It is also worth noting that the degree of ageing in the population has an impact on the assessment of poverty among the elderly.
\end{abstract}

Keywords: poverty; population ageing; public services and tasks; municipalities; local self-government units

\section{Introduction}

The subject literature analyses the broadly-understood problems of poverty in various aspects. The causes and the effects of the occurrence of this socioeconomic problem, as well as the challenges that it entails, are researched. The general policy directions in the area of reducing poverty are defined at the central level; however, in accordance with the principle of subsidiarity, some tasks are delegated for execution by local self-government units. In view of the demographical changes occurring in the society, the issue of poverty is taking on a particular meaning. This study fills a research gap in the perception of the problem of poverty by local self-government units (SGUs). The topic taken up is part of the discussion on combating poverty as one of the goals included in the Europe 2020 strategy. Due to the fact that the European Commission adopts not only averaged targets for the entire European Union (EU) but also relates them to the socioeconomic situation of individual EU members, the authors found it interesting to examine poverty in a specific country in the context of an aging population.

Bearing in mind the above premises, a research problem was undertaken in the form of questions: Is poverty a significant social issue for local self-government units, and are there differences in the assessment of the incidence of this phenomenon depending on the type of municipality? Do the ongoing demographic changes related to population ageing influence the assessment of the extent of poverty by municipalities? Derivatives 
of the undertaken research problem are the main aims of the study, which include: a review of the definition of poverty, a description of the tasks of municipalities in the field of counteracting the problem of poverty, and an analysis and assessment of the impact of ageing on the perception of poverty.

The structure of the study is a consequence of the above-mentioned objectives. The first part encompasses an analysis of the subject literature in the scope of poverty and the evolution of the ways in which it is understood. The second part involves considerations regarding the task's implementation in the field of the prevention of poverty by municipalities in the context of an ageing population. The third part goes on to discuss the methodology of the conducted research, while the fourth section presents the results, which have permitted us to answer the research questions. The paper is concluded with a summary which contains the most important conclusions of the analyses and identifies potential directions for further research.

\section{Literature Review}

\subsection{The Issue of Poverty in the Subject Literature}

The findings on the phenomenon of poverty can be diverse, which results from the adoption of varying definitions of poverty and measurement methods [1]. Today, poverty is defined as the inability to meet one's needs-materially, spiritually, or sociallywhich is associated with the inability to make one's own choices [2]. In other words, the prevention of an individual from realising their life aspirations may be associated with the phenomenon of poverty, although it is necessary to determine the boundaries of poverty (the issue of determining basic needs) because of the limitlessness of human needs.

The concept of poverty and social exclusion presented by the European Commission raises the question of the relationship between these notions. On the one hand, the broad definition of poverty assumed above leads to the conclusion that it also encompasses social exclusion [3]. On the other hand, poverty may become a factor leading to social alienation, although other grounds may also have an impact on exclusion. A distinct border between poverty and social exclusion appears when it is assumed that poverty is a lack of material and monetary resources, while-from a sociological point of view-social exclusion is associated with non-participation in economic, social, political or cultural life [4,5].

Sen defines poverty in terms of the deprivation of the ability to, or the lack of real capabilities in the implementation of one's life plans; he does not specify basic abilities, citing examples such as the ability to meet one's own nutritional needs, the ability to achieve physical fitness, the possession of appropriate clothing and housing, or access to social participation only in some works. He argues that there should not be a permanent universal list of capabilities that varies across societies according to the functions and corresponding abilities that are considered valuable, although it is permissible to define some specific lists for empirical research on poverty in a given society [6].

The United Nations (UN) uses a different explanation of poverty, defining it as a "condition characterised by severe deprivation of basic human needs, including food, safe drinking water, sanitation facilities, health, shelter, education and information. It depends not only on income but also on access to services" [7].

Similarly, Salejko-Szyszczak and Szczepaniak associate poverty with a lack of sufficient material resources for life, and the resulting inability to obtain basic goods [8]. Furthermore, they believe that poverty is a sign of dissatisfaction, or of human needs met to an insufficient degree, which refers to people whose resources are too limited to ensure a standard of living that is not lower than the minimum that is acceptable in their country of residence. The authors also grade poverty, and state that absolute poverty is the inability to meet one's minimum needs. This concerns a relatively small part of the population which, due to a lack of income, is permanently marginalised. In turn, relative poverty results from significant differences in the standard of living of the members of a given society, and is defined as a form of inequality between different social groups. This applies to a larger 
group of people whose marginalisation begins when their income reaches a level well below the average that is available in society [9].

Townsend and Sen present a broad perspective on poverty [10,11]. The authors also point to the difference between poverty in the absolute and relative dimensions. Sen, who prefers an absolute approach to poverty, recognised some advantages of relative definitions [11,12]. He believes that the absolute concepts of poverty might indeed simplify reality too greatly, but the relative conception of poverty does not recognise certain aspects of poverty. An important issue in the determination of poverty is to consider capabilities as an absolute element, but—at the same time-it is a debatable issue which goods we should consider as indispensable. Sen manifests his fears about a rigid relativistic view, which may assume that poverty cannot be eliminated, because in every society there will be people with lower material status, although they possess the minimum conditions necessary for a modest life. As a result, it is difficult to distinguish the problem of poverty from the general discussion of inequality in any society, because poverty can remain unchanged even with decreasing social inequalities.

From Sen's perspective, the determination of the options that are fundamental, when it comes to meeting material and non-material needs, is something that varies from one society to another, and therefore-in this context-it can be considered a relative aspect. On the other hand, attempts at a relative measurement of poverty, especially following Townsend's proposal, are criticised in terms of arbitrariness, taking only into consideration the living standards in the particular community which is being analysed [12]. It should be emphasised, however, that both in relative and absolute terms, the adopted lines or rates change over time, which results from social and economic development.

We may observe that the distinction between absolute and relative concepts of poverty is often inconclusive. Researchers who assume the absolute definition of poverty try to measure it indirectly, generally considering disposable income as a key variable by the determination of the degree that is necessary to achieve a minimum level of consumption. Meanwhile, according to the second approach, attempts are being made to determine the basket of goods in accordance with local food and consumption standards, which may in turn indicate the income necessary to maintain living standards in a given society [1,12].

The relative definition of poverty is measured in a direct way, recognising the standards for the consumption of goods and the social conditions as belonging to a given society, and therefore the notion of deprivation becomes the key concept here. Townsend proposes an indicator of material and social deprivation which would include various phenomena related to poverty [3]:

- as aspects of material deprivation: diet, clothing, housing, environmental and working conditions.

- $\quad$ as aspects of social deprivation: the lack of employment rights, family activity, integration with the community, participation in social institutions, and access to education and recreation.

Regardless of the definition of poverty, most researchers try to measure poverty using an intermediate measure, or the poverty line [13-15]. However, the poverty line approach comes with many limitations, which is why poverty line surveys are best considered as an assessment of the risk of poverty. In turn, the analysis of deprivation is more directly related to the standard of life, and aims to establish whether people can afford items which are commonly recognised as necessary in today's society. These elements are identified on the basis of the views prevailing in society, surveys and interviews, and are determined by assessing the ability of individuals to acquire the necessary goods, and not by comparing their income with the poverty line [16]. It should be noted that one can also find Townsend's measures to be quite arbitrary, similarly to the limits of poverty, if it is the researcher who determines the social priorities of a given community [12].

A survey on the nature of poverty in developing countries was carried out by Banerjee and Duflo [17]. The authors focus on examining the motivation of people identified as poor when making decisions about the consumption of food, health, education, family size, 
finances, and access to services, etc. The research shows that the perception of poverty in developed and developing countries may vary, which is influenced by, among other things, way of life, mentality and culture. Meanwhile, Stiglitz draws attention to the perception of the problem of poverty in the context of globalization phenomena and the emerging mismatch of the policies of international organizations and the solutions imposed by them on the social situation of individual countries [18].

Another means to measure poverty is the combination of both direct and indirect methods through a multidimensional approach to poverty, which would be linked with Sen's conviction about the merging of absolute and relative measures [19-21]. The presentation of poverty in a multidimensional approach is visible in the measurements made by Eurostat (measuring poverty using three sub-indicators: monetary poverty, material deprivation and low work intensity) and partly also by the Statistics Poland (using equivalent measures in the form of the determination of relative poverty in relation to the level of expenditure, extreme poverty, and statutory poverty).

The UN also draws attention to measuring poverty in the multidimensional aspect. In the second half of the 1990s, the United Nations introduced the Human Poverty Index (HPI), which then split into two indicators: one for developing countries and the other for developed countries [22]. In 2010, HPI was replaced by the global Multidimensional Poverty Index, for which data is collected under the auspices of the United Nations Development Programme and the Oxford Poverty and Human Development Initiative (OPHI) [23-28]. It concerns more than 100 developing countries, and identifies poverty across 10 indicators in health, education, and standard of living.

The poverty measurement was also reflected in the 2030 Agenda, which established 17 Sustainable Development Goals (SDGs) agreed upon by all 193 UN member states [29,30]. The member states are gradually trying to implement sustainable development goals into their development strategies, and their progress is then reported in annual reports. Most of the data come from international organizations (OECD, UNICEF, WHO, the World Bank,), but the data is also obtained from household surveys (Gallup World Poll) and civil society [31,32].

However, the three indices included in SDG 1 'No poverty' cannot be considered sufficient to measure poverty, or to unequivocally state whether the phenomenon occurs or not (they measure the poverty headcount ratio at USD 1.90 per day, the poverty headcount ratio at USD 3.20 per day, and the poverty rate after taxes and transfers). More information on poverty can be found in other SDGs, e.g., the prevalence of undernourishment, the population using at most basic sanitation services, access to electricity, the employmentto-population ratio, and the elderly poverty rate. It should be emphasized that the SDGs presented in special editions for the European Union are measured on the basis of the aforementioned very detailed data on poverty provided by Eurostat (European Union Statistics on Income and Living Conditions - EUSILC) [33].

A noteworthy aspect of the measurement of SDGs is the introduction of the term "leave no one behind", i.e., reducing inequalities between people (inequalities in income and wealth; inequalities in access to public services and infrastructure; gender inequalities; and inequalities in access, for example to food, health, and education). Reducing the degree of inequality should be treated more broadly than the reduction of the level of poverty, and it should also be remembered that decreasing disparities do not necessarily mean reducing poverty as such [34]. As a consequence, the new Leave-No-One-Behind Index (LNOB) was created, for the determination of the degree of inequality in EU countries with a broad range of measures which are also part of the SDG Index. The disaggregated LNOB dashboard is divided into four groups: extreme poverty and material deprivation, income inequality, access to and quality of services (healthcare, education), and gender inequality [33]. In the case of the first group of indices, we distinguished the elderly poverty rate, which is defined as the percentage of people over the age of 65 whose income falls below the poverty line, taken as half the median household income of the total population. Out of all of the EU member states, the level of the index was positively assessed in eight 
countries. At the same time, it should be stressed that, in all these countries, there is a trend that consists in the growing number of the elderly who are at risk of poverty. Concurrently, in 13 countries where the level of the index ranges from 7.7 to 14.2 , the indicator did not reach the designated SDG level and, moreover, three of these countries (Belgium, Austria, Slovenia) experienced an increase in this index. This group also includes Poland. In the third group, there are only three countries (Lithuania, Latvia, Estonia) for which the indicator ranges from 25.1 to 35.7 , but its value has declined over the last three years.

Studies on poverty have increasingly focused on population ageing and its implications for the financial position of individuals, in particular the elderly. The quality of life of older people and the experience of income poverty in the United Kingdom was ana-lysed by Price [35]. Kaida and Boyd [36], who investigated the support of the government and family co-resistance in reducing poverty among seniors in Canada. The issues and processes that lead people into poverty on the individual, community, and political levels were described by Rissanen and Ylinen [37]. The question of poverty in the light of demographic change, taking into account both elderly and nonelderly people, was addressed in an article written by Mohd, Senadjki and Mansor [38]. The substantial risk of poverty among seniors was also indicated by Rašticová et al. [39], who analyzed the problem in the Czech Republic. International statistics presented by the International Labor Organization also confirm the high risk of poverty among the elderly in most countries around the world [40]. In turn, Mavrikiou, Pivoriene, and Xhumari, who examined the impact of pension systems on the extension of working life in Albania, Cyprus and Lithuania, emphasize that even changes in the pension system consisting in raising the retirement age do not ensure the well-being of seniors. The authors highlight the need for a broad-based discussion on the possibility of extending working life by the active involvement of the elderly [41]. Maj-Waśniowska and Wałega point to the differentiation of symptoms of material deprivation between single-person households of people over and under 65 years of age [42].

\subsection{The Implementation by Municipalities of Tasks Related to Counteracting Poverty in the Context of Population Ageing}

The results of the last official social cohesion survey conducted by Statistics Poland in 2018 [43] on a sample of 13,000 people over the age of 15 showed that $59 \%$ of people thought that material support for people living in poverty is primarily a task for the state, and over a third (about 36\%) claimed that it is a task for both the state and the family, which proves high social support for state interventionism in providing material support for the poor and reducing income disparities. In the public's opinion, the most important form of aid for people living in poverty is help in finding a job (43\% of respondents consider it one of the three most needed forms of support). Social services, in the form of assistance in the care of the chronically ill and disabled persons (approx. 32\%), increasing the availability of free medical services (approx. 28\%), and assistance in running the household for the elderly (approx. 25\%) are also of great importance.

The cited research results have become the starting point for considerations on the implementation of social policy in the context of demographic changes. It follows that society quite clearly indicates the need for the state's engagement and significant activity in actions aimed at reducing poverty. Considering the occurring demographic processes and their implications for the pension system, in the long term, this may mean not only a change of the scope of the tasks implemented in this area but also the necessity to increase the intensity of state activities.

Tasks in the field of the prevention of poverty and social exclusion are implemented both at the central and local government units level. Local self-government units in Poland play a major role in the implementation of public tasks. Local self-government in Poland was reactivated after the political transformation in 1990 at the lowest municipal level. Two further levels of self-government, i.e., poviat and voivodeships, were established in 1999. As of 1 January 2021, the administrative division of Poland included: 16 voivodeships, 314 poviats, 66 cities with poviat rights (municipalities that perform poviat tasks on 
the terms specified in the Act on Poviat Self-Government), and 2477 municipalities. A distinction is drawn between three types of municipalities: urban municipalities (302), the borders of which coincide with the border of the city forming the municipality (urban municipalities may also be cities with poviat rights); urban-rural municipalities (652), which include both cities within administrative borders and areas beyond the towns' limits; and rural municipalities (1523), which do not have towns in their territory.

For the most part, the prevention of poverty and social exclusion is connected with the realisation of a specific social policy. As far as the strategies, goals, and means of the realisation of those tasks are determined in governmental documents, the main burden of realising these tasks in that scope falls on local self-government units. The activities undertaken under the social assistance system aimed at reducing the phenomenon of poverty consist primarily in the payment of cash benefits, but also in various forms of support in the form of non-cash benefits. According to article 36 of the Act of 12 March 2004 on social assistance in the first case, these include, among others: permanent benefits; periodic benefits; purpose-specific or special-purpose benefits; benefits and loans for economic self-empowerment, help for self-empowerment, and for continuing education; and the remuneration due to the guardian for providing care granted by the court [44]. The condition for granting cash benefits is meeting the income criteria of the so-called 'statutory poverty line' set out in the Regulation of the Council of Ministers of 11 July 2018 on verified income criteria and the amounts of cash benefits from social assistance [45]. In the light of the aforementioned Act, non-cash benefits include: social work; credit tickets; health insurance contributions; social security contributions; material assistance, including for economic self-empowerment, giving a funeral, specialist counselling, crisis intervention, shelter, meals, and necessary clothes; care services in the place of residence, support centres, and family care homes; specialist care services in the place of residence and in support centres; protected housing, stay and services in a social welfare home; help in obtaining adequate housing conditions, including in a sheltered flat; help in finding employment; and assistance in development for independent persons [44].

In addition to the benefits mentioned under social policy, supportive measures are also carried out. Examples of such activities are schemes such as the multiannual programme 'State aid in nutrition' [46], or the Food Assistance Operational Programme 2014-2020 (FAOP) [47]. The first of those programmes provides the municipality's financial support in the scope of nutrition, and it was implemented in order to limit the phenomenon of the malnutrition of children and adolescents from low-income or disadvantaged families, and adults, in particular lonely and elderly people. On the other hand, the FAOP consists in the distribution of food by non-governmental organisations (NGOs) at three levels: national, regional, and local. The programme aims to provide nutrition to the most deprived persons - those experiencing the deepest forms of poverty - in the form of packages and/or meals, and the implementation of accompanying activities supporting the social inclusion of the recipients of food aid [48]. Furthermore, the Ministry of Family, Labour and Social Policy supports local self-government units in implementing their own tasks through departmental programmes directed at groups at particular risk of social exclusion, e.g., people experiencing violence, homeless people, socially-excluded people, and people with mental disorders [48].

Similarly, as with every catalogue of benefits granted as part of social aid, the tasks of SGUs realised in order to counteract poverty were determined in the act on social assistance. Among local self-government units, the largest range of tasks was entrusted to municipalities, as the units located closest to the citizens, and which were thus able to best recognise the needs of the local community and fulfil them. Among the tasks of a municipality in social assistance, we distinguish [44]:

(1) The municipality's own tasks, including those of a mandatory nature (for example, developing and implementing a municipal strategy for solving social problems, preparing an assessment of social assistance resources based on an analysis of the local social and demographic situation, granting and paying permanent and peri- 
odic benefits and various types of targeted benefits in cash, maintaining a social assistance centre).

(2) Commissioned tasks in the field of government administration, like organising and providing specialist care services in the place of residence for people; implementing tasks arising from government social assistance programmes, aimed at protecting the standard of living of individuals, families and social groups; and social assistance programmes.

An analysis of the nature of the municipality's tasks in the scope of social policy indicates that the occurring demographic changes and the progressive ageing of the population will, from the long-term perspective, require the increased activity of municipalities in this area. This will apply in particular to tasks involving both direct financial support (the payment of periodic and special-purpose benefits) and the organisation and provision of care services, including those of a specialist nature, both in the place of residence and by running and providing places in social assistance homes. The progressive ageing of the population may also mean an increase in municipalities' expenses on paying pension contributions for persons who resign from work due to the need to provide personal care for a long-term or seriously ill family member. The projected changes in the population of Poland clearly indicate a growing percentage of older people, which in 2060 will amount to $33.87 \%$ of the total population, meaning an increase of 12.8 percentage points compared to 2025. Moreover, the phenomenon accompanying the ageing process is double aging, the consequence of which is the doubling of the number of people aged 80 and more-the projected share of this group in society in 2060 is over $12 \%$ (Table 1, based on [49]). Similar changes, although slightly less severe, can observed in the whole European Union. The projected percentage of people aged 65+ in 2060 will be higher than that in 2025 by 8.03 pp, and in the case of people aged $80+$, this change will be equal to $6.16 \mathrm{pp}$.

Table 1. Forecasted population in Poland and the European Union in the years 2025-2060.

\begin{tabular}{|c|c|c|c|c|c|c|c|c|}
\hline Specification & 2025 & 2030 & 2035 & 2040 & 2045 & 2050 & 2055 & 2060 \\
\hline \multicolumn{9}{|c|}{ Poland } \\
\hline Total number of people (thousand) & 37,567 & 37,018 & 36,369 & 35,662 & 34,897 & 34,102 & 33,306 & 32,520 \\
\hline Number of people aged 65+ (thousand) & 7915 & 8397 & 8637 & 9013 & 9598 & 10,268 & 10,759 & 11,014 \\
\hline Share of people aged $65+(\%)$ & 21.07 & 22.68 & 23.75 & 25.27 & 27.50 & 30.11 & 32.30 & 33.87 \\
\hline Number of people aged $80+($ thousand) & 1695 & 2092 & 2729 & 3265 & 3359 & 3316 & 3515 & 3998 \\
\hline Share of people aged $80+(\%)$ & 4.51 & 5.65 & 7.50 & 9.16 & 9.63 & 9.72 & 10.55 & 12.29 \\
\hline \multicolumn{9}{|c|}{ European Union } \\
\hline Total number of people (thousand) & 449,297 & 449,122 & 448,234 & 446,755 & 444,472 & 441,221 & 437,086 & 432,474 \\
\hline Number of people aged 65+ (thousand) & 100,029 & 108,520 & 116,819 & 123,145 & 127,581 & 130,164 & 131,338 & 131,013 \\
\hline Share of people aged $65+(\%)$ & 22.26 & 24.16 & 26.06 & 27.56 & 28.70 & 29.50 & 30.05 & 30.29 \\
\hline Number of people aged $80+$ (thousand) & 28,629 & 32,214 & 36,516 & 41,077 & 45,736 & 49,930 & 52,596 & 54,176 \\
\hline Share of people aged $80+(\%)$ & 6.37 & 7.17 & 8.15 & 9.19 & 10.29 & 11.32 & 12.03 & 12.53 \\
\hline
\end{tabular}

The need for the greater engagement of the state, including that of SGUs, in the area of social policy, especially in tasks related to the elderly will result, however, not only from changes in the demographic structure of society, but also due to changes in the material situation of seniors. According to the report of the European Commission [50], in 2060, the average replacement rate in the European Union will be lower by $12.3 \mathrm{pp}$. Only two countries project an increase of the replacement ratios over the projection period (Bulgaria and the Czech Republic). On the other hand, alongside Spain, Greece, and Estonia, Poland belongs to the countries for which the biggest decrease in the replacement rate is forecast. In 2060, the replacement rate in Poland will be 28.7\%, which means that, compared to 2013, it will decline by $24.4 \mathrm{pp}$. By comparison, in Spain, the replacement rate will be lower by 30.4 pp, in Greece by 16.4 pp, and in Estonia by 14.9 pp. The Social Security Office forecasts for Poland are even more pessimistic. According to the data of the Office, in 
2050 , the average pension will be $28.7 \%$ of the average salary, and in 2060 only $24.6 \%$ [51]. In 2080 , it will be only $23.1 \%$ [52]. This means that the level of pensions will be much lower than at present, and thus the number of elderly people requiring additional state support-not only of financial nature-will increase. It is true that, currently, the percentage of households of retirees experiencing extreme poverty, taking into account the criterion of socioeconomic groups, is one of the lowest against the background of other groups, but we should note the increase of extreme poverty from 3.9\% to $4.6 \%$ over the years 2010-2018 [53,54]. According to research conducted at McMaster University in a group of 26 selected Organisation for Economic Cooperation and Development (OECD) countries, the poverty rate after taxes and transfers in the general population in $58 \%$ of the surveyed countries is higher than that in the group of older adults (66+) [55]. Nevertheless, we should take into account that this situation will reverse in the perspective of the coming decades due to the declining replacement rate forecast for most countries, and the growing number of people of retirement age.

Despite the fact that-in line with the public opinion research-at present, $36 \%$ of people think that help to people living in poverty is both the task of the state and family, it should be expected that the ongoing socio-civilization changes, including a change in the model of family functioning, will cause social expectations regarding the role of the state in supporting people affected by poverty, disability, or social exclusion to increase.

\section{Materials and Methods}

According to Sustainable Development Solutions Network and the Institute for European Environmental Policy, the elderly poverty rate included in the above-mentioned Leave-No-One-Behind Index for Poland is below the EU's average [33]. The selection of the Małopolskie Voivodeship for the research results from the fact that, in the period 2017-2019, the poverty rates provided by the Statistics Poland (extreme poverty rate, relative poverty rate, statutory poverty rate) always significantly exceeded the national average, placing the region in the top three voivodeships with the highest poverty rates. A key objective of this research will be to assess the significance of poverty as a social issue for local selfgovernment units, and to indicate the differences in the assessment of the incidence of this phenomenon in the context of an aging society. In this study, we used a relative approach based on the opinions of representatives of local government units on the intensification of the ageing processes and poverty in the areas of the municipalities they represent. In the proposed approach, the assessment of poverty by municipalities is based on the opinions of municipalities' staff who are directly involved in the implementation of tasks for the local community, rather than the analysis of statistical data on the extent or severity of poverty in the municipality, as before [56-61]. Such an approach is based on the conviction that people who are responsible for the execution of tasks with respect to social policy in municipalities, while remaining in direct contact with residents, have the greatest opportunity to identify specific social issues.

Based on the aim of the article and previous studies on poverty, we have put forward the following research hypotheses:

Hypothesis (H1). The assessment of the level of poverty in a municipality depends on: (a) the type of municipality, (b) the number of inhabitants, (c) the demographic structure of the local community, (d) the subjective assessment of the ageing processes taking place in a given municipality;

Hypothesis (H2). There exists a relationship between the assessment of the level of poverty among the elderly in the municipality and a subjective study of the society's ageing process.

The basis for the formulation of such hypotheses were studies on combating poverty and social exclusion as part of the policy implemented by local government units, which demonstrated that activities in this respect are of little effect, and that the perception of social problems may be influenced by the size of the studied municipality [62]. The size of 
a rural settlement and the degree of urbanization as determinants of poverty have been discussed many times [4,63-68].

The data for the research of the assessment of poverty at the municipality level were obtained from the survey conducted as part of the project "The problems and challenges of local self-government units in the era of an ageing population". The survey was sent to 181 local self-government units. Reponses were provided by 144 municipalities, which gave data on $80 \%$ of the municipalities in the Małopolskie Voivodeship. The survey was conducted using the Computer Assisted Web Interviews (CAWI) method, in cooperation with the Regional Chamber of Audit in Kraków. On behalf of individual municipalities, the answers were mainly provided by the treasurers ( $49.62 \%$ of the total responders), secretaries of the office $(16.79 \%)$, heads of relevant departments or projects $(13.74 \%)$, local government executives $(6.87 \%)$, persons employed as an inspector $(3.05 \%)$, deputies of local government executives $(1.53 \%)$, and deputy treasurers $(1.53 \%)$. It should be noted that the assessment of poverty and the aging of the population in municipalities is based only on the subjective feelings of municipal employees, and not on objective facts.

In order to verify whether there is a relationship between the researched qualitative variables, we used the Chi-Square test of independence. The null hypothesis in the ChiSquare test is that the variables are independent. This test is based on the comparison of empirical values (obtained in the study) and theoretical values (calculated on the assumption that there is no relationship between the variables). Large differences point to the existence of a relationship between the variables. The test statistics for variable $X$ having $r$ variants and variable $Y$ having $\mathrm{c}$ variants is calculated according to the formula [69]:

$$
\chi^{2}=\sum_{i=1}^{r} \sum_{j=1}^{c} \frac{\left(O_{i j}-E_{i j}\right)^{2}}{E_{i j}},
$$

where $O$ is the observed value, and $E$ is the expected value.

In order to determine the relationships occurring between the categories of variables characterising the scale of incidence of poverty in the researched municipalities and the remaining variables, we conducted a correspondence analysis. The advantage of this analysis is that it enables the accurate recognition of the co-existence of categories of variables or objects measured on the ordinal or nominal scale. Of significance here is the lack of exorbitant requirements on the distribution to which the analysed variables should be subject. The main purpose of correspondence analysis is to reconstruct the distance between points representing the rows and columns of a multivariate table in a space with fewer dimensions, while maintaining as much of the initial information as possible [70,71]. All of the statistical analyses were performed using the IBM SPSS Statistics 25 and Statistica 13.3 packages.

\section{Results and Discussion}

The study included 144 municipalities, of which $68 \%$ constituted rural municipalities, $24 \%$ were urban-rural municipalities, and $6 \%$ were urban municipalities. Cities with poviat rights constituted only $2 \%$ of the municipalities surveyed. Among the surveyed entities, municipalities with a population of 15-50 thousand (34 municipalities) and 7.5-10 thousand (33 municipalities) dominated. The distribution of the number of municipalities by the number of inhabitants is presented in Figure 1. 


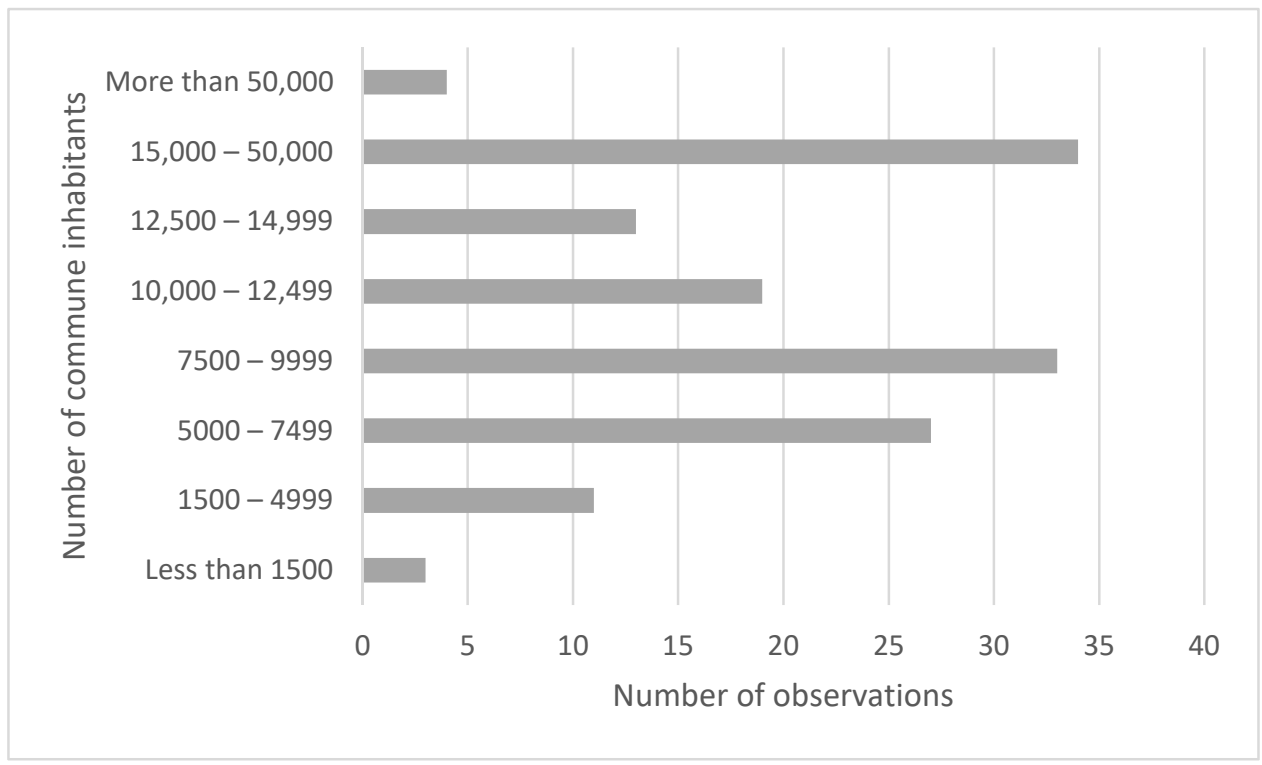

Figure 1. Distribution of the studied municipalities by population.

In the light of the progressing population ageing, we also analysed the municipalities by the age structures of their inhabitants. The surveyed entities were dominated by municipalities with a percentage of people of post-working age (i.e., older than 65 years) of $12-14 \%$ (45 municipalities) and $14-16 \%$ (42 municipalities) (Figure 2). The average percentage of older people in the analysed municipalities was 14.71, with a standard deviation of $2.49 \%$.

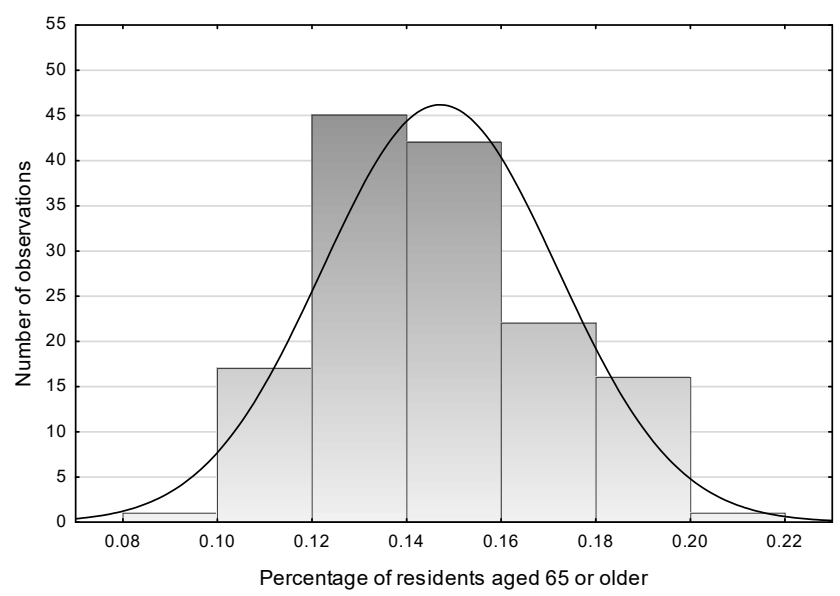

Figure 2. Distribution of the surveyed municipalities by the percentage of post-working age residents.

In the study, we assessed the level of poverty in a given entity. In the case of $14 \%$ of the surveyed municipalities, they provided answers indicating that poverty does not occur in their unit, and $74 \%$ of municipalities believed that poverty does occur there. Only one municipality assessed poverty as very intense within its borders. However, it is worrying that as many as $12 \%$ of the entities did not have an opinion on the level of poverty occurring in their area. This may indicate an insufficient recognition of the range of poverty in these entities. There is therefore a risk that insufficient awareness of the prevalence of a particular problem in the municipality will result in a lack of appropriate measures on the part of the local authorities. This problem already exists now, as recognised by the results of research pointing to the poor performance of territorial self-government entities in the scope of counteracting poverty [62]. The lack of a proper response on the part of the local authorities over the long term may add to the failure to adjust the scope and quality of 
goods and services to the expectations of the local community. Bonfiglioli enumerates three possibilities for the testing of the local government's attempt to achieve better performance in favour of the poor: local empowerment in decision-making, local social governance, and promoting the local economy [72].

As shown in Table 2, the type of municipality does not impact the assessment of the level of poverty risk. According to the employees of municipality offices, the problem of poverty occurs in about three-quarters of municipalities (73\% of rural municipalities, $74 \%$ of urban-rural municipalities, and $75 \%$ of urban municipalities). The issue of poverty also concerns two of the three cities with poviat rights. These results corroborate the research conducted so far, which indicates that the level of poverty only slightly depends on the type of municipality, and to a much greater extent on its geographic location. The geographic analysis of poverty is related to the spatial poverty trap as a result of unfavorable geographical factors [73]. In this context, attention is paid to factors that may affect the level of poverty, such as: the geographical distance from cities; the lack of appropriate infrastructure, i.e., roads, public transport; public utility institutions; access to services; and difficult living conditions due to climate or natural terrain [74-76]. All of these elements can make up geographic isolation [77]. It should be noted that getting out of poverty (poverty exit) in such areas is more difficult, which results from the socalled 'bad neighborhood effect', i.e., despite the knowledge, skills and education, external factors may hinder or even prevent the development of investments in such areas (lack of opportunity) [73]. The lack of differences in the assessment of the level of poverty in individual types of municipalities may also stem from the method of assessing this phenomenon being based on a relative approach, rather than objective criteria. This is demonstrated by the fact that, in 2019, the population of beneficiaries of social assistance in Poland was mostly rural. Its number was 904,800 people, which accounted for $51.4 \%$ of the total beneficiaries group. The share of beneficiaries in the number of inhabitants was $5.9 \%$ in rural areas, and smaller by $2.1 \mathrm{pp}$ in urban areas [78]. This results from the fact that, from the point of view of communal social policy and the priorities set out in strategy papers, local government units should primarily build on absolute measures. A relative approach to poverty, based on a consideration of municipal representatives, could result in the underestimation of the risk of belonging to the poverty area and, consequently, could contribute to the marginalization of this important social issue.

Table 2. Assessment of the level of poverty in the municipality, and the type of local self-government unit.

\begin{tabular}{|c|c|c|c|c|c|c|c|}
\hline \multirow{2}{*}{$\begin{array}{l}\text { Assessment of the Level of } \\
\text { Poverty in the Municipality }\end{array}$} & \multicolumn{6}{|c|}{ Type of Local Self-Government Unit } & \multirow{2}{*}{ Chi2 } \\
\hline & City $v$ & Rights & Urban & Urban-Rural & Rural & Total & \\
\hline \multirow{2}{*}{ I have no opinion } & $\mathrm{N}$ & 1 & 0 & 6 & 10 & 17 & \multirow{9}{*}{$\begin{array}{c}\text { Chi2 }=5.6552 \\
\text { df }=9 \\
p=0.77\end{array}$} \\
\hline & $\%$ & 33.33 & 0.00 & 17.14 & 10.20 & 11.81 & \\
\hline \multirow{2}{*}{ Does not occur } & $\mathrm{N}$ & 0 & 2 & 3 & 15 & 20 & \\
\hline & $\%$ & 0.00 & 25.00 & 8.57 & 15.31 & 13.89 & \\
\hline \multirow{2}{*}{ Occurs } & $\mathrm{N}$ & 2 & 6 & 26 & 72 & 106 & \\
\hline & $\%$ & 66.67 & 75.00 & 74.29 & 73.47 & 73.61 & \\
\hline \multirow{2}{*}{ Very intense } & $\mathrm{N}$ & 0 & 0 & 0 & 1 & 1 & \\
\hline & $\%$ & 0.00 & 0.00 & 0.00 & 1.02 & 0.69 & \\
\hline Total & $\mathrm{N}$ & 3 & 8 & 35 & 98 & 144 & \\
\hline
\end{tabular}

Regarding the number of municipality residents, it should be concluded that it does not impact the level of assessment of the incidence of poverty in the municipality (Chi2 $=4.8561, \mathrm{df}=9, p=0.8467)$. According to the employees of municipalities, the issue of poverty concerns $71 \%$ of municipalities with a population below $5000,74 \%$ of municipalities with a population of 5-15 thousand and $15-50$ thousand, and $75 \%$ of municipalities with a population of over 50 thousand. In every fifth municipality with less than 
5000 residents, employees have no opinion on such an important issue as the incidence of poverty among their residents. Such results may be explained, as in the case of the absence of dependence between the type of municipality and the assessment of poverty, by evaluation through the prism of the geographical criterion. It should also be clarified that, on the one hand, the absence of an opinion on the prevalence of poverty may stem from the fact that municipalities recognize the needs of inhabitants at risk of poverty independently only to a small extent. According to the report of the Supreme Audit Office, only in six out of 21 audited units were there isolated cases in which the support for people living in poverty was granted ex officio and not at the request of the interested parties. On the other hand, the need to respect the privacy of inhabitants makes it difficult for municipalities to reach people in need with help. It is thus necessary to broadly disseminate information on the possibilities and principles of obtaining aid [79].

The third of the adopted criteria for the division of municipalities of the Małopolskie Voivodeship is the percentage of elderly people. The division of municipalities according to the participation of older people was made on the basis of the variable quartiles. As such, the first quartile group of the municipality was labelled as 'young', the second as 'rather young', the third as 'rather old', and the fourth as 'old' (Table 3). The values of the individual quartiles are $0.1272,0.1437$ and 0.1625 , respectively. Although the Chi2 statistics for the variables 'assessment of the level of poverty' and 'participation of the elderly in the municipality' are not statistically significant, it can be seen that the problem of poverty most often concerns the municipalities with the highest share of people in post-working age (over $80 \%$ ).

Table 3. Assessment of the level of poverty and the percentage of the elderly in the municipalities.

\begin{tabular}{|c|c|c|c|c|c|c|c|}
\hline \multicolumn{2}{|c|}{$\begin{array}{l}\text { Assessment of the Level of Poverty in } \\
\text { the Municipality }\end{array}$} & \multirow{2}{*}{$\begin{array}{c}\text { Young } \\
2\end{array}$} & \multirow{2}{*}{$\begin{array}{c}\text { Rather Young } \\
3\end{array}$} & \multirow{2}{*}{$\begin{array}{c}\text { Rather Old } \\
8\end{array}$} & \multirow{2}{*}{$\begin{array}{c}\text { Old } \\
4\end{array}$} & \multirow{2}{*}{$\begin{array}{c}\text { Total } \\
17\end{array}$} & \multirow[t]{2}{*}{ Chi2 } \\
\hline Lbora noninion & $\mathrm{N}$ & & & & & & \\
\hline I nave no opinion & $\%$ & 5.56 & 8.33 & 22.22 & 11.11 & 11.81 & \multirow{8}{*}{$\begin{array}{c}\text { Chi } 2=10.6 \\
\mathrm{df}=9 \\
\mathrm{p}=0.3042\end{array}$} \\
\hline \multirow{2}{*}{ Does not occur } & $\mathrm{N}$ & 7 & 6 & 4 & 3 & 20 & \\
\hline & $\%$ & 19.44 & 16.67 & 11.11 & 8.33 & 13.89 & \\
\hline \multirow{2}{*}{ Occurs } & $\mathrm{N}$ & 27 & 27 & 23 & 29 & 106 & \\
\hline & $\%$ & 75.00 & 75.00 & 63.89 & 80.56 & 73.61 & \\
\hline \multirow{2}{*}{ Very intense } & $\mathrm{N}$ & 0 & 0 & 1 & 0 & 1 & \\
\hline & $\%$ & 0.00 & 0.00 & 2.78 & 0.00 & 0.69 & \\
\hline Total & $\mathrm{N}$ & 36 & 36 & 36 & 36 & 144 & \\
\hline
\end{tabular}

The ageing of society means not only the deterioration of the material situation of seniors resulting from the decrease in the replacement rate, but also an increase in the demand for services, including in the field of long-term health care. Gragnolati, Jorgensen, Rocha, and Fruttero showed the relationship between the aging of the society and the level of poverty, and the impact of this process on public finances and the provision of goods and services [80]. A description of the relationship between aging and poverty with particular attention to the most vulnerable individuals at each end of the age distribution can also be found in work of Marchand and Smeeding [81].

Municipality employees were also asked to assess the ageing processes taking place in their municipality. The distribution of answers to this question was as follows: $2.78 \%$, I have no opinion; $3.47 \%$, low; $9.72 \%$, rather low; 59.72 , average; $17.36 \%$, rather high; $6.25 \%$, high. One of the municipalities $(0.69 \%)$ did not answer this question. There was no relationship between the subjective assessment of the intensity of the ageing process and the assessment of the level of poverty in the municipality (Chi2 $=6.87, \mathrm{df}=9, p=0.6509$ ).

The lack of awareness of this correlation may have negative implications in the longterm planning of municipal policy. This may lead to an underestimation of the risk of poverty and, as a consequence, a maladjustment of the scope of local goods and services to 
the needs of the inhabitants. A confirmation of the poor recognition of these processes by municipalities are the binding strategy papers. In strategies for solving social problems, poverty issues were most often presented in the general sociodemographic analysis, and were usually described in the context of other social issues (unemployment, disability, and long-term or severe illness). Oftentimes, these documents are not updated or adapted to changing socioeconomic conditions. In the case of $10 \%$ of the municipalities surveyed by the Supreme Audit Office, these documents entered into force more than 10 years ago [79].

Another part of the study concerns the incidence of poverty among older people (65+). According to respondents, for $14 \%$ of the municipalities, poverty among older people is not a problem. In $68 \%$ of the municipalities, older people are considered to be moderately affected by poverty. However, in $13 \%$ of the municipalities, this phenomenon is considered a serious problem. In $5 \%$ of the municipalities, the employees did not have an opinion on poverty among the elderly. It should be noted that old-age poverty entails many types of exclusions from social, physical, and mental well-being [37]. In this context, special consideration could be given to taking account of the experiences of various age groups in order to effectively counteract this problem and develop appropriate social work practices.

When analysing the assessment of the level of poverty among older people in individual types of municipalities, some differences are noticeable, but they are not statistically significant (Chi2 $=15.71, \mathrm{df}=9, p=0.0732)$. On the other hand, after the merging of urban municipalities and cities with poviat rights into one category, we observe that the test probability is at the border (assuming a significance level of $\alpha=0.1$, the existence of a relationship between the assessment of the level of poverty among the elderly in the municipality and the type of municipality could be considered) (see Table 4).

Table 4. Assessment of the level of poverty among the elderly and the type of municipality (three categories).

\begin{tabular}{|c|c|c|c|c|c|c|}
\hline \multicolumn{2}{|c|}{$\begin{array}{l}\text { Assessment of the Level of Poverty } \\
\text { among the Elderly }\end{array}$} & \multirow{2}{*}{$\begin{array}{c}\text { City with Poviat Rights or Urban } \\
0\end{array}$} & \multirow{2}{*}{$\begin{array}{c}\text { Urban-Rural } \\
4 \\
\end{array}$} & \multirow{2}{*}{$\begin{array}{c}\text { Rural } \\
4 \\
\end{array}$} & \multirow{2}{*}{$\begin{array}{c}\text { Total } \\
8 \\
\end{array}$} & \multirow[t]{2}{*}{ Chi2 } \\
\hline I hou po & $\mathrm{N}$ & & & & & \\
\hline inave no opmion & $\%$ & 0.00 & 11.43 & 4.08 & 5.56 & \multirow{8}{*}{$\begin{array}{c}\text { Chi2 }=12.16 \\
\mathrm{df}=6 \\
\mathrm{p}=0.0585\end{array}$} \\
\hline \multirow{2}{*}{ Does not cause a problem } & $\mathrm{N}$ & 1 & 2 & 17 & 20 & \\
\hline & $\%$ & 9.09 & 5.71 & 17.35 & 13.89 & \\
\hline \multirow{2}{*}{ Affects to a moderate degree } & $\mathrm{N}$ & 6 & 24 & 68 & 98 & \\
\hline & $\%$ & 54.55 & 68.57 & 69.39 & 68.06 & \\
\hline \multirow{2}{*}{ Is a serious problem } & $\mathrm{N}$ & 4 & 5 & 9 & 18 & \\
\hline & $\%$ & 36.36 & 14.29 & 9.18 & 12.50 & \\
\hline Total & & 11 & 35 & 98 & 144 & \\
\hline
\end{tabular}

The largest percentage of the municipalities which believe that poverty among the elderly does not cause a problem can be found among rural municipalities (as much as $17 \%$ ). For comparison, only $6 \%$ of urban-rural municipalities think similarly. The problem of poverty among the elderly, to a moderate degree, concerns $55 \%$ of urban municipalities or cities with poviat rights, $69 \%$ of urban-rural municipalities, and the same number of rural municipalities. However, the highest percentage of the municipalities which consider the poverty of the elderly to be a serious problem was recorded in urban municipalities and cities with poviat rights (36\%). For the sake of comparison, merely $9 \%$ of rural the municipalities consider poverty among the elderly to be a serious problem. According to the survey, the highest percentage of the municipalities that do not see the poverty of older people as a problem in their area was recorded among municipalities with between 5000 and 15,000 residents (18\%). As a rule, these municipalities are of a rural nature, which confirms the above conclusions. Poverty among the elderly is considered a serious problem by $7 \%$ of the municipalities numbering up to 5000 inhabitants, $12 \%$ of the municipalities with a population of 5-15 thousand, $11 \%$ of the municipalities with $15-50$ thousand inhabitants, and as many as half of the largest municipalities (with more 
than 50,000 inhabitants). These differences are not statistically significant (Chi2 $=11.52$, $\mathrm{df}=9, p=0.2419)$.

The above findings diverge from the majority of research results presented in the literature $[37,38,77,82]$. Assessment of poverty among seniors in rural municipalities may stem from the fact that the average income of rural residents is lower than that of inhabitants in towns, and thus-in urban municipalities-the reference point is different than in urban or urban-rural ones [83,84]. This situation should give an impetus to implementing appropriate reforms at the local level, which will reduce the risk of the negative effects of poverty among older people in the future. In the literature on the subject, research on eradicating poverty among the elderly by existing local arrangements that provide support for older persons, and how the elderly are affected by poverty vis-à-vis the rest of the population are conducted on selected examples [85-87]. It was observed that, in a situation where "the ageing process does not imply a serious obstacle to the aim of reducing poverty, general and local governments in particular face a great opportunity to make the reforms needed to reduce old age poverty, and to create the environment for old age poverty not to be a serious concern in the future" [87].

Considering the criteria of the age structure among the studied entities, the poverty of older people is not a problem in $17 \%$ of the municipalities in the first quartile group, $11 \%$ of the second quartile group, $19 \%$ of the third quartile group, and $8 \%$ of the municipalities with the highest percentage of people in post-working age. The poverty of the elderly is considered to be a moderate problem by $72 \%$ of the municipalities with a percentage of people of post-productive age below the median, and $67 \%$ of the municipalities from the third quartile group, and $61 \%$ from the fourth quartile group. Poverty among the elderly is considered to be a serious problem by $6 \%, 11 \%$, and $8 \%$ from the first, second and third quartile groups, respectively, and $25 \%$ of the municipalities from the fourth quartile group. The indicated differences are not statistically significant (Chi2 $=8.89, \mathrm{df}=9, p=0.4472$ ).

The assessment of the level of poverty among the elderly depends on the subjective assessment of the intensity of the ageing process in the municipality (see Table 5). Among municipalities that assess the intensity of the ageing process as high or rather high, only one believes that the poverty of the elderly is not a problem within its borders. However, as many as $56 \%$ of the municipalities assessing the intensity of the ageing process as high see the poverty of the elderly as a serious problem.

Table 5. Assessment of the level of poverty among the elderly and the intensity of the ageing process in municipalities.

\begin{tabular}{|c|c|c|c|c|c|c|c|c|c|}
\hline \multicolumn{2}{|c|}{$\begin{array}{l}\text { Assessment of the Level of Poverty } \\
\text { among the Elderly }\end{array}$} & \multirow{2}{*}{$\begin{array}{c}\text { I have No Opinion } \\
1\end{array}$} & \multirow{2}{*}{$\begin{array}{c}\text { Low } \\
0\end{array}$} & \multirow{2}{*}{$\begin{array}{c}\text { Rather Low } \\
1\end{array}$} & \multirow{2}{*}{$\begin{array}{c}\text { Average } \\
4\end{array}$} & \multirow{2}{*}{$\begin{array}{c}\text { Rather High } \\
2\end{array}$} & \multirow{2}{*}{$\begin{array}{c}\text { High } \\
0\end{array}$} & \multirow{2}{*}{$\begin{array}{c}\text { Total } \\
8 \\
\end{array}$} & \multirow[t]{2}{*}{ Chi2 } \\
\hline & $\mathrm{N}$ & & & & & & & & \\
\hline I have no opinion & $\%$ & 25.00 & 0.00 & 7.14 & 4.65 & 8.00 & 0.00 & 5.59 & \multirow{8}{*}{$\begin{aligned} \text { Chi2 } & =30.07 \\
\text { df } & =15 \\
p & =0.0117\end{aligned}$} \\
\hline \multirow{2}{*}{ Does not cause a problem } & $\mathrm{N}$ & 1 & 0 & 5 & 13 & 1 & 0 & 20 & \\
\hline & $\%$ & 25.00 & 0.00 & 35.71 & 15.12 & 4.00 & 0.00 & 13.99 & \\
\hline \multirow{2}{*}{ Affects to a moderate degree } & $\mathrm{N}$ & 2 & 4 & 7 & 60 & 20 & 4 & 97 & \\
\hline & $\%$ & 50.00 & 80.00 & 50.00 & $69.77 \%$ & 80.00 & 44.44 & 67.83 & \\
\hline \multirow{2}{*}{ Is a serious problem } & $\mathrm{N}$ & 0 & 1 & 1 & 9 & 2 & 5 & 18 & \\
\hline & $\%$ & 0.00 & 20.00 & 7.14 & 10.47 & 8.00 & 55.56 & 12.59 & \\
\hline Total & $\mathrm{N}$ & 4 & 5 & 14 & 86 & 25 & 9 & 143 & \\
\hline
\end{tabular}

An undoubtedly positive assessment should be attributed to the awareness of the lack of dependence between the intensification of the aging process in the municipality and an increased risk of old-age poverty. This confirms the results of Kubejko-Polańska, who indicated the awareness of local authorities regarding the existence of the key problem, which is population ageing [88]. In the strategy papers of the municipalities, it is treated as one of the challenges of local policy. That said, it is not portrayed in the categories of opportunities and chances, but rather as a source of difficulties. The answer to this challenge is the development of the silver economy at the local level [89-91]. In line with the 
concept of the silver economy, the growing proportion of elderly people in the population translates into an increase in the aggregate purchasing power of older consumers, which can be used as a stimulus for local development. Nevertheless, the burgeoning silver market has not yet been recognized as an opportunity for socioeconomic development. None of the analysed documents contained a provision that the advancement of the silver economy could have an impact on the improvement of the economic situation in individual municipalities [92].

The dependencies between the assessment of the level of poverty among the elderly and the assessment of the intensity of the ageing process in the municipality are presented graphically in Figure 3.

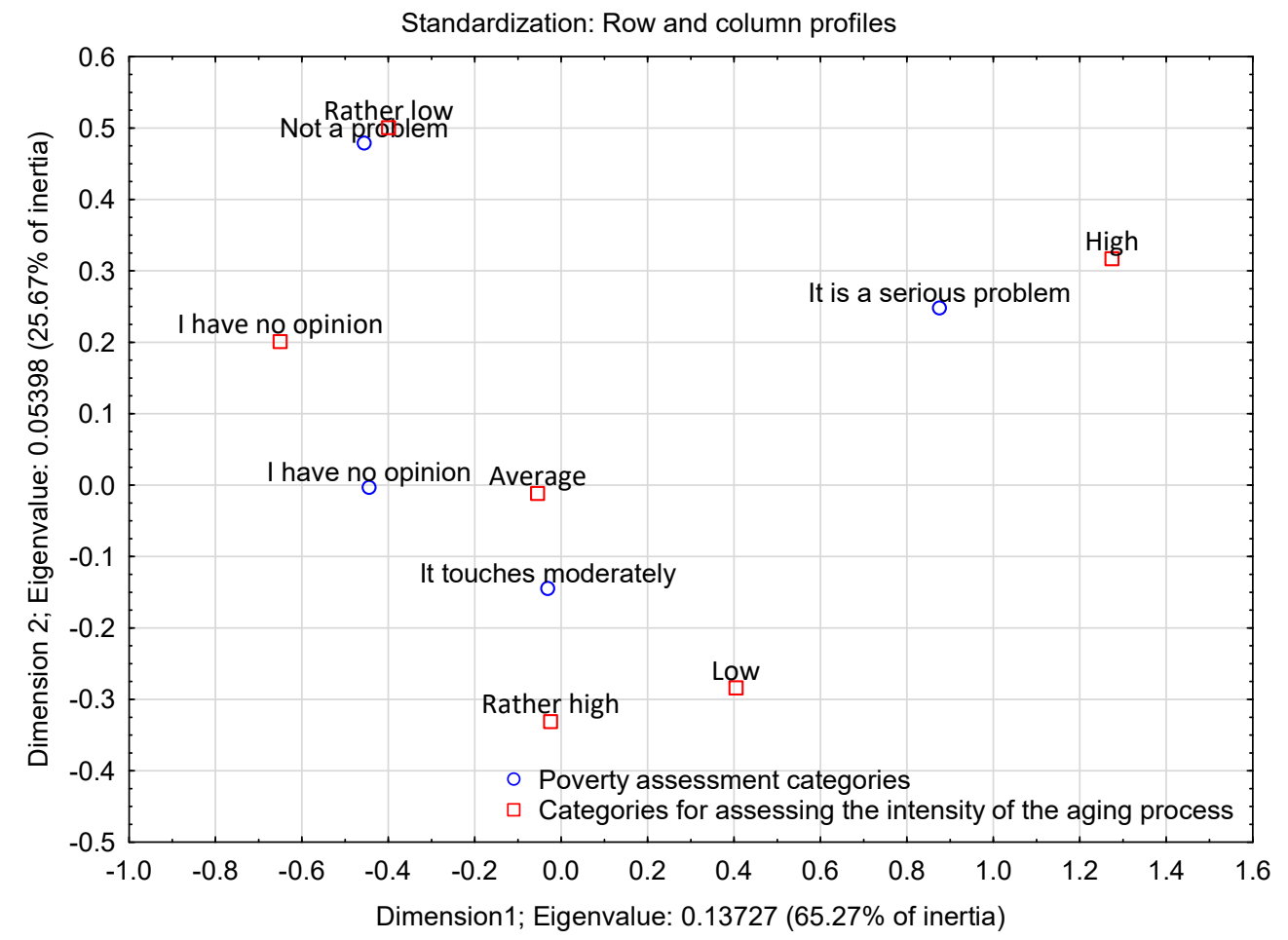

Figure 3. Interdependency of the categories of the assessment of the level of poverty among the elderly and the assessment of the intensity of ageing in the municipality.

The municipalities which assessed the intensity of ageing as high are more likely to see the poverty of the elderly as a serious problem compared to other entities. On the other hand, the municipalities that considered the intensity of the ageing process to be rather low more often than other entities were of the opinion that the poverty of the elderly is not a problem. In turn, the municipalities which assessed the intensity of the ageing process as average more often than other municipalities had no opinion on the assessment of the level of poverty among the elderly.

Although the issues raised in the study are based on Polish experiences, the conclusions drawn from the conducted analyses also have a broader international context. Considering the obtained results, we should note that the employees of municipality offices assess the issue of poverty as one of the most serious; however, they do not see the correlation between the ageing population and the level of poverty in general. Such as assessment seems to testify to the low degree of awareness of the future effects of the occurring demographic changes. As a consequence, it may turn out that a larger engagement of the municipalities in actions aimed at ensuring a series of services to an increasing number of older people, for a much longer period, is necessary. The ageing of society means not only the deterioration of the material situation of seniors resulting from the decrease in the replacement rate, but also an increase in the demand for services, including 
in the field of long-term health care. This is due to the increase in life expectancy and the phenomenon of double ageing, which means a longer life in retirement. Mei, Hsu, and Ou wrote about the need to provide economic support to the elderly in the conditions of the aging of the Chinese society [93]. The impact of changes in local authority spending on social care for older people, taking account of the important relationship between the National Health Service and social care services in meeting the needs of older people was examined by Humphries, Thorlby, Holder, Hall and Charles [94]. Zeng, Wang, Zhang and $\mathrm{Xu}$ conducted a comparative analyses of long-term care costs between China and other countries in an aging society. They indicated that the examination of the costs of different chronic diseases may be an effective way to develop private long-term care insurance and realize the effective complementarity between private long-term care insurance and public long-term care insurance [95]. Studies on the differences in the level of long-term care costs were also conducted by Lagergren, Kurube, and Saito [96].

\section{Conclusions}

The results of the survey conducted in the municipalities of the Małopolskie Voivodeship indicate that as many as $74 \%$ of the municipalities are struggling with the issue of poverty. Furthermore, this problem occurs regardless of the type of municipality. It is observed by $73 \%$ of rural municipalities, $74 \%$ of urban-rural municipalities, $75 \%$ of urban municipalities, and $66 \%$ of cities with poviat rights. Similarly to the type of the municipality, the number of residents does not impact the assessment of the incidence of poverty. We did not observe a dependency between the subjective assessment of the intensity of the ageing process and the assessment of the poverty level in the municipality. On the other hand, the classification of the municipalities by age structure allows the conclusion that, in the examined municipalities, the problem of poverty most often concerns municipalities with the highest share of people of post-working age (over $80 \%$ ); however, this relationship is not statistically significant. Therefore, we should reject the H1 hypothesis according to which the assessment of the poverty level in a municipality depends on: (a) the type of municipality, (b) the number of inhabitants, (c) the demographic structure of the local community, and (d) a subjective assessment of the ageing processes taking place in a given municipality.

Although there is no relationship between the subjective assessment of the demographic changes related to population ageing and the assessment of the level of poverty in the municipality, this relationship occurs when assessing the intensity of the ageing process and assessing the level of poverty among the elderly. There is, therefore, no reason to reject the $\mathrm{H} 2$ hypothesis that there exists a relationship between the assessment of the level of poverty among older people in the municipality and the subjective assessment of population ageing. The municipalities assessing the intensification of population ageing as high believe that poverty among the elderly is a serious problem more often than other entities. On the other hand, a rather low assessment of the intensity of this process is accompanied by the belief that the poverty of the elderly is not a problem. In total, more than $80 \%$ of the municipalities indicate the problem of elderly poverty as serious or moderate.

Summing up, the following has to be re-emphasized: the risk of poverty and social exclusion concerns people of different age groups. That said, this problem is especially related to the elderly and, taking account of the progressive aging process and the declining replacement rate, it can be expected to grow. In this context, special consideration might be given to the account of the experiences of various age groups in order to effectively counteract this problem and develop appropriate social work practices. An undoubtedly positive assessment should be attributed to the awareness of the lack of dependence between the intensification of the aging process in the municipality and increased risk of old-age poverty. Nevertheless, the measures aimed at counteracting poverty are not treated as a priority in the strategy papers of the municipalities. Hence, on a practical level, municipalities should use the potential of the development of the silver economy. It can not only limit the negative effects of the social processes in act but also, above all, stimulate local 
development. However, in order to make this possible, municipalities must make correctly recognise the problems occurring in their territory. For this purpose, local government units must rely on absolute measures, rather than their own subjective assessment of the situation, which could result in the underestimation of the risk of belonging to the poverty area, and consequently contribute to the marginalization of this important social issue. The experiences of the employees of local government units in the field of cooperation with residents can help to explore the specific problems of the local community, but should not constitute the basis for the assessment of their extent.

It seems worthwhile to note that the conducted research can constitute the basis for further in-depth analyses. In the theoretical aspect, it seems interesting to consider the scope of tasks carried out by local self-government units to reduce the problem of poverty in the conditions of progressing demographic change. It is also worth verifying the conclusions formulated herein based on research extended to other countries.

Author Contributions: Conceptualization, M.Ć., K.M.-W. and K.S.-C.; methodology, M.Ć., K.M.-W. and K.S.-C.; formal analysis, M.Ć., K.M.-W. and K.S.-C.; investigation, M.Ć., K.M.-W. and K.S.-C.; resources, M.Ć., K.M.-W. and K.S.-C.; writing-original draft preparation, M.Ć., K.M.-W. and K.S.-C.; writing-review and editing, M.Ć., K.M.-W. and K.S.-C. All authors have read and agreed to the published version of the manuscript.

Funding: This project was financed by the Ministry of Science and Higher Education within the 'Regional Initiative of Excellence' Programme for 2019-2022. Project no.: 021/RID/2018/19. Total financing: 11897 131.40 PLN.

Institutional Review Board Statement: Not applicable.

Informed Consent Statement: Informed consent was obtained from all of the subjects involved in the study.

Data Availability Statement: Not applicable.

Conflicts of Interest: The authors declare no conflict of interest.

\section{References}

1. Panek, T. Ubóstwo i wykluczenie społeczne. In Statystyka Społeczna; Panek, T., Ed.; Polskie Wydawnictwo Ekonomiczne: Warsaw, Poland, 2014.

2. Baczewski, G. Teoretyczne problemy definiowania ubóstwa w polityce społecznej. Ann. Univ. Mariae Curie Sklodowska Sec. H Oecon 2004, 38, 161-174.

3. Townsend, P. Deprivation. J. Soc. Policy 1987, 16, 125-146. [CrossRef]

4. Panek, T.; Zwierzchowski, J. Porównawcza analiza sfery ubóstwa w krajach UE w ujęciu regionalnym. Isid Work. Pap. 2013, 35, 1-117.

5. Lecerf, M. Poverty in the European Union. The Crisis and Its Aftermath; European Parliament: Directorate-General for Parliamentary Research Services, European Union: Brussels, Belgium, 2016.

6. Sen, A. Development as Freedom; Alfred A. Knopf: New York, NY, USA, 2000.

7. The Copenhagen Declaration and Programme of Action. In Proceedings of the United Nations World Summit for Social Development, New York, NY, USA, 6-12 March 1995.

8. Salejko-Szyszczak, I.; Szczepaniak, M. The risk of poverty and social exclusion in Poland in the period 2006-2015 in the comparison to the European Union countries. Econ. Law 2017, 16, 201-217. [CrossRef]

9. Szymkowiak, M.; Beręsewicz, M.; Bieńkuńska, A.; Jastrzębski, P.; Jaworska, M.; Józefowski, T.; Klimanek, T.; Kowalewski, J.; Łysoń, P.; Młodak, A.; et al. Pomiar Ubóstwa na Poziomie Powiatów_Etap II; Centrum Badan i Edukacji Statystycznej GUS: Jachranka, Poland, 2015.

10. Townsend, P. Poverty in the United Kingdom; Penguin Books: Harmondsworth, UK, 1979.

11. Sen, A. Poor, relatively speaking. Oxf. Econ. Pap. 1983, 35, 153-169. [CrossRef]

12. Mendonça dos Santos, T. Poverty as lack of capabilities: An analysis of the definition of poverty of Amartya Sen. Riv. Int. Filos. Psicol. 2017, 2, 125-148.

13. Szarfenberg, R. Ubóstwo i Wykluczenie Społeczne w Polsce. Pomiar, Wyjaśnianie, Strategie Przeciwdziałania; Friedrich-Ebert-Stiftung Przedstawicielstwo w Polsce wspólnie z Fundacją Międzynarodowe Centrum Badań i Analiz (ICRA): Warsaw, Poland, 2012.

14. Szukiełojć-Bieńkuńska, A. Pomiar ubóstwa i wykluczenia społecznego w urzędowej statystyce polskiej. In Pomiar Ubóstwa. Zmiany Koncepcji i Ich Znaczenie; Topińska, I., Ed.; Instytut Pracy i Spraw Socjalnych: Warsaw, Poland, 2008 ; pp. 3-19. 
15. Kędzierska, M.; Łuczak, M.J.; Mazur-Łuczak, J.; Nowosielska, A.; Nowosielski, M.; Jabkowski, P. Społeczno-Ekonomiczne Wymiary Ubóstwa w Perspektywie Różnic Terytorialnych w Wielkopolsce; Regionalny Ośrodek Polityki Społecznej w Poznaniu, Obserwatorium Integracji Społecznej: Poznan, Poland, 2013.

16. Saunders, P. Researching poverty: Methods, results and impact. Econ. Labour Relat. Rev. 2013, 24, 205-218. [CrossRef]

17. Banerjee, A.; Duflo, E. Poor Economics: A Radical Rethinking of the Way to Fight Global Poverty; Public Affairs: New York, NY, USA, 2011.

18. Stiglitz, J.E. Globalizationa and Its Discontents; W.W. Norton \& Company: New York, NY, USA, 2002.

19. Burchi, F.; Malerba, D.; Rippin, N.; Montenegro, C.E. Comparing Global trends in Multidimensional and Income Poverty and Assessing Horizontal Inequalities. Die Discuss. Pap. 2019, 2. [CrossRef]

20. Oxford Poverty and Human Development Initiative. Global Multidimensional Poverty Index 2018: The Most Detailed Picture to Date of the World's Poorest People; University of Oxford: Oxford, UK, 2018.

21. Panek, T. Multidimensional approach to poverty measurement: Fuzzy measures of the incidence and the depth of poverty. SiT 2010, 11, 361-379.

22. Kubiczek, A. Jak mierzyć dziś rozwój społeczno-gospodarczy krajów? Soc. Inequalities Econ. Growth 2014, 38, 40-56.

23. Alkire, S.; Foster, J. Counting and Multidimensional Poverty Measurement. J. Public Econ. 2011, 95, 476-487. [CrossRef]

24. Alkire, S. How to Measure the Many Dimensions of Poverty? Oxford Poverty and Human Development Initiative (OPHI); Organization for Economic Cooperation and Development (OECD): Oxford, UK, 2013.

25. Alkire, S.; Foster, J.E.; Seth, S.; Santos, M.E.; Roche, J.M.; Ballon, P. Multidimensional Poverty Measurement and Analysis; Oxford University Press: Oxford, UK, 2015.

26. Alkire, S.; Kanagaratnam, U.; Suppa, N. The Global Multidimensional Poverty Index (MPI): 2018 Revision; OPHI MPI Methodological Notes 46; University of Oxford: Oxford, UK, 2018.

27. Alkire, S.; Conceição, P.; Barham, A.; Calderón, C.; Conconi, A.; Dirksen, J.; Espinal, F.C.; Evans, M.; Hall, J.; Jahic, A.; et al. Global Multidimensional Poverty Index. Illuminating Inequalities; United Nations Development Programme and Oxford Poverty and Human Development Initiative: New York, NY, USA, 2019; Available online: https:/ / ophi.org.uk/wp-content/uploads/G-MPI_ Report_2019_PDF.pdf (accessed on 26 February 2021).

28. Alkire, S.; Conceição, A.; Calderón, C.; Dirksen, J.; Evans, M.; Gonzales, R.; Hall, J.; Jahic, A.; Kanagaratnam, U.; Kivilo, M.; et al . Charting Pathways out of Multidimensional Poverty: Achieving the SDGs; United Nations Development Programme and Oxford Poverty and Human Development Initiative: New York, NY, USA, 2020; Available online: http:/ /hdr.undp.org/en/2020-MPI (accessed on 15 November 2020).

29. United Nations. The Sustainable Development Goals Report 2019; United Nations Publications; Department of Economic and Social Affairs: New York, NY, USA, 2019.

30. Global Sustainable Development Report 2019: The Future is Now-Science for Achieving Sustainable Development; United Nations, Independent Group of Scientists: New York, NY, USA, 2019.

31. Cuaresma, J.C.; Fengler, W.; Kharas, H.; Bekhtiar, K.; Brottrager, M.; Hofer, M. Will the Sustainable Development Goals be fulfilled? Assessing present and future global poverty. Palgrave Commun. 2019, 4, 29. Available online: http://worldpoverty.io/ (accessed on 15 November 2020). [CrossRef]

32. Sachs, J.; Schmidt-Traub, G.; Kroll, C.; Lafortune, G.; Fuller, G. Sustainable Development Report 2019; Bertelsmann Stiftung and Sustainable Development Solutions Network (SDSN): New York, NY, USA, 2019.

33. The 2019 Europe Sustainable Development Report; Sustainable Development Solutions Network and Institute for European Environmental Policy: Brussels, Belgium, 2019.

34. Sen, A.K. Inequality Reexamined; Clarendon Press: Oxford, UK, 1992.

35. Price, D. The poverty of older people in the UK. J. Soc. Work Pr. 2006, 20, 251-266. [CrossRef]

36. Kaida, L.; Boyd, M. Poverty Variations among the Elderly: The Roles of Income Security Policies and Family Co-Residence. Can. J. Aging 2011, 30, 83-100. [CrossRef]

37. Rissanen, S.; Ylinen, S. Elderly poverty: Risks and experiences-A literature review. Nord. Soc. Work Res. 2014, 4, 144-157. [CrossRef]

38. Mohd, S.; Senadjki, A.; Mansor, N. Trend of Poverty among Elderly: Evidence from Household Income Surveys. J. Poverty 2016. [CrossRef]

39. Rašticová, M.; Kubíčková, L.; Bédiová, M.; Antošová, V.; Birčiaková, N.; Abramuszkinová-Pavlíková, E. Analysis of the Standards of Seniors' Living: Case Study of the Czech Republic. In Proceedings of the Knowledge for Market Use 2016, Our Interconnected and Divided World, International Scientific Conference, Societas Scientiarum Olomucensis II, Olomouc, Czech Republic, 8-9 September 2016; pp. 405-409.

40. ILO. World Social Protection Report 2014/15: Building Economic Recovery, Inclusive Development and Social Justice; International Labour Office: Geneva, Switzerland, 2014.

41. Mavrikiou, P.; Pivoriene, J.; Xhumari, M. The impact of pension systems on working life in Albania, Cyprus and Lithuania. In Proceedings of the 21th International Scientific Conference, Enterprise and Competitive Environment: Brno, Czech Republic, 22-23 March 2018; pp. 424-433. 
42. Maj-Waśniowska, K.; Wałega, A. Material deprivation of older people in European Union countries in the context of the ageing society. In Proceedings of the 21th International Scientific Conference, Enterprise and Competitive Environment: Brno, Czech Republic, 22-23 March 2018; pp. 391-404.

43. Postrzeganie ubóstwa i nierówności dochodowych w Polsce. Wyniki Badania Spójności Społecznej 2018; Statistics Poland: Warsaw, Poland, 2018.

44. Ustawa $z$ dnia 12 Marca 2004 o Pomocy Społecznej (Act of 12 March 2004 on Social Assistance); OJ of 2019, Item 1507 Later Amended. Available online: https://isap.sejm.gov.pl/isap.nsf/download.xsp/WDU20040640593/U/D20040593Lj.pdf (accessed on 15 November 2020).

45. Rozporządzenie Rady Ministrów z dnia 11 Lipca 2018 r. w Sprawie Zweryfikowanych kryteriów Dochodowych Oraz Kwot świadczeń Pieniężnych z Pomocy Społecznej (Regulation of the Council of Ministers of 11 July 2018 on Verified Income Criteria and Amounts of Cash Benefits from Social Assistance); OJ of 2018, Item 1358. Available online: http://isap.sejm.gov.pl/isap.nsf/download.xsp/WDU201 80001358/O/D20181358.pdf (accessed on 15 November 2020).

46. Obwieszczenie Prezesa Rady Ministrów z dnia 21 Sierpnia 2015 r. w Sprawie Ogłoszenia Jednolitego Tekstu Uchwały Rady Ministrów w Sprawie Ustanowienia Wieloletniego Programu Wspierania Finansowego Gmin w Zakresie Dożywiania "Pomoc Państwa w Zakresie Dożywiania" na Lata 2014-2020 (Announcement of the Prime Minister of 21 August 2015 on the Publication of a Uniform Text of the Resolution of the Council of Ministers on Establishing a Multiannual Programme of Financial Support for Municipalities in the Field of Nutrition "State Aid in Nutrition" for the Years 2014-2020 "State Aid in Nutrition" for the Years 2014-2020); M. P. 2015, Item 821. Available online: http:/ / isap.sejm.gov.pl/isap.nsf/download.xsp/WMP20150000821/O/M20150821.pdf (accessed on 15 November 2020).

47. Ministry of Labour and Social Policy. In Program Operacyjny Pomoc Żywnościowa 2014-2020; Ministry of Labour and Social Policy: Warsaw, Poland, 2014. Available online: https:/ / www.gov.pl/web/rodzina/podstawy-prawne (accessed on 15 November 2020).

48. Ministry of Labour and Social Policy. Przeciwdziałanie ubóstwu w Polsce (Counteracting Poverty in Poland); Biuro Promocji: Warsaw, Poland, 2018; Available online: https:/ / www.gov.pl/web / rodzina/przeciwdzialanie-ubostwu-w-polsce (accessed on 15 November 2020).

49. Population on 1st January by Age, Sex and Type of Projection. Available online: https://appsso.eurostat.ec.europa.eu/nui/show. do?dataset=proj_19np\&lang=e (accessed on 5 December 2020).

50. European Union. The 2015 Ageing Report Economic and Financial Affairs Economic and Budgetary Projections for the 28 EU Member States (2013-2060); European Economy 3 2015; Publications Office of the European Union: Luxembourg, 2015.

51. Szymański, D. Niepokojące wieści z ZUS. Wskazują na to Najnowsze Dane o Emeryturach POLAKÓW. Available online: www. businessinsider.com.pl (accessed on 5 December 2020).

52. Wojciechowski, P. Komentarz Głównego Ekonomisty ZUS do Prognozy Wpływów i Wydatków Funduszu Emerytalnego do 2080 r. Available online: www.zus.pl (accessed on 5 December 2020).

53. Statistics Poland. Ubóstwo w Polsce w 2010 r. (na Podstawie Badania Budżetów Gospodarstw Domowych); Departament Badań Społecznych i Warunków Życia: Warsaw, Poland, 2011.

54. Statistics Poland. Zasięg Ubóstwa Ekonomicznego w Polsce w 2018 r. (na Podstawie Wyników Badania Budżetów Gospodarstw Domowych); Departament Badań Społecznych i Warunków Życia: Warsaw, Poland, 2019.

55. Waddell, K.; Panchal, P.; Wilson, M.G. Identifying Indicators and Rates of Poverty Among Older Adults; McMaster University: Hamilton, ON, Canada, 2018.

56. Berbeka, J. Ubóstwo subiektywne w Małopolsce: Studium przypadku. Polityka Społeczna 2001, 9, 16-20.

57. Mikuła, A. Stopień zagrożenia ubóstwem w powiatach i gminach województwa mazowieckiego. Wiadomości Stat. 2016, 61, 60-74.

58. David, A.; Guilbert, N.; Hamaguchi, N.; Higashi, Y.; Hino, H.; Leibbrandt, M.; Shifa, M. Spatial Poverty and Inequality in South Africa: A Municipality Level Analysis; Working Paper Number 221; Southern Africa Labour and Development Research Unit: Cape Town, South Africa, 2018.

59. Costa, G.O.T.; Machado, A.F.; Amaral, P.V. Vulnerability to poverty in Brazilian municipalities in 2000 and 2010 : A multidimensional approach. Economia 2018, 19, 132-148. [CrossRef]

60. Błędowski, P.; Broda-Wysocki, P.; Golinowska, S.; Kubicki, P.; Grotowska-Leder, J.; Warzywoda-Kruszyńska, W. Państwo, Samorzady, Organizacje Pozarządowe i Wspólnoty Lokalne Wobec Ubóstwa i Wykluczenia Społecznego; IPiSS: Warsaw, Poland, 2007.

61. Pham, A.T.Q.; Mukhopadhaya, P.; Vu, H. Estimating poverty and vulnerability to monetary and non-monetary poverty: The case of Vietnam. Empir. Econ. 2021. [CrossRef]

62. Błędowski, B.; Kubicki, P. Zwalczanie ubóstwa i wykluczenia społecznego w ramach polityki realizowanej na szczeblach samorządu terytorialnego. Polityka Społeczna 2006, 11, 36-38.

63. Raczkowska, M.; Wrzesińska-Kowal, J. Inequality and economic poverty in rural areas of Poland. Ann. Agric. Econ. Rural Dev. 2018, 105, 7-17.

64. Copus, A.; Melo, P.C.; Kaup, S.; Tagai, G.; Artelaris, P. Regional poverty mapping in Europe—Challenges, advances, benefits and limitations. Local Econ. 2015, 30, 742-764. [CrossRef]

65. Saczewska-Piotrowska, A. Dynamika ubóstwa w miejskich i wiejskich gospodarstwach domowych, Sączewska-Piotrowska, A. (2016). Dynamika ubóstwa w miejskich i wiejskich gospodarstwach domowych. Wiadomości Statystyczne 2016, 7, 39-59.

66. Quintano, K.C.; Castellano, R.; Punzo, G. Estimating Poverty in the Italian Provinces using Small Area Estimation Models. Metodološki Zv. 2007, 4, 37-70. 
67. Lehtonen, R.; Veijanen, A. Small Area Estimation Poverty by Model Calibration. J. Indian Soc. Agric. Stat. 2012, 66, 125-133.

68. Molina, I.; Rao, J.N.K.; Nandram, B. Small Area Estimation of General Parameters with Application to Poverty Indicators: A Hierarchical Bayes Approach. Ann. Appl. Stat. 2014, 8, 852-885. [CrossRef]

69. Aczel, A.D.; Sounderpandian, J. Statystyka w Zarzadzaniu, 2nd ed.; Wydawnictwo Naukowe PWN: Warsaw, Poland, 2018.

70. Panek, T.; Zwierzchowski, J. Statystyczne Metody Wielowymiarowej Analizy Porównawczej. Teoria i Zastosowania; Oficyna Wydawnicza Szkoły Głównej Handlowej: Warsaw, Poland, 2013.

71. Stanisz, A. Przystępny Kurs Statystyki z Zastosowaniem STATISTICA PL na Przyktadach z Medycyny; Statsoft Polska sp. z o. o.: Krakow, Poland, 2007; Volume 3.

72. Bonfiglioli, A. Empowering the Poor. Local Governance for Poverty Reduction; United Nations Capital Development Fund: New York, NY, USA, 2003.

73. Bird, K. Addressing Spatial Poverty Traps; Overseas Development Institute, Chronic Poverty Advisory Network: London, UK, 2019.

74. Li, T.; Cao, X.; Qiu, M.; Li, Y. Exploring the Spatial Determinants of Rural Poverty in the Interprovincial Border Areas of the Loess Plateau in China: A Village-Level Analysis Using Geographically Weighted Regression. Int. J. Geo-Inf. 2020, 9, 345. [CrossRef]

75. Ćwiek, M.; Maj-Waśniowska, K.; Stabryła-Chudzio, K. Spatial Differentiation of Poverty in Polish Voivodships. Cent. Eur. Manag. J. 2020, 28, 2-25. [CrossRef]

76. Aaberge, R.; Langørgen, A.; Mogstad, M.; Østensen, M. The Impact of Local Public Services and Geographical Cost of Living Differences on Poverty Estimates; IZA Discussion Paper No. 3686; IZA: Bonn, Germany, 2008.

77. Madanipour, A.; Shucksmith, M.; Talbot, H. Concepts of poverty and social exclusion in Europe. Local Econ. 2015, 30, 721-741. [CrossRef]

78. Statistics Poland. Beneficjenci Środowiskowej Pomocy Społecznej w 2019 r; 2020. Available online: https://stat.gov.pl/obszarytematyczne/warunki-zycia/ubostwo-pomoc-spoleczna/beneficjenci-srodowiskowej-pomocy-spolecznej-w-2019-roku,6,9. html (accessed on 5 December 2020).

79. Najwyższa Izba Kontroli. Pomoc Świadczona Przez Gminy Osobom Żyjacym w Ubóstwie. Informacja o Wynikach Kontroli; Nr ewid.12/2020/P/19/041/KPS; Najwyższa Izba Kontroli: Warsaw, Poland, 2020.

80. Gragnolati, M.; Jorgensen, O.H.; Rocha, R.; Fruttero, A. Growing Old in an Older Brazil Implications of Population Aging on Growth, Poverty, Public Finance and Service Delivery; World Bank Publications: Washington, DC, USA, 2011.

81. Marchand, J.; Smeeding, T. Poverty and Aging. In Handbook of the Economics of Population Aging; Piggott, J., Woodland, A., Eds.; Elsevier: Amsterdam, The Netherlands, 2016; Volume 1, pp. 905-950.

82. Cawthorne, A. Elderly Poverty: The Challenge Before Us; Center for American Progress: Washington, DC, USA, 2008.

83. Raczkowska, M. Nierówności dochodowe w Polsce w relacji miasto-wieś. Zesz. Nauk. Szkoły Głównej Gospod. Wiej. 2015, 112, 111-124. [CrossRef]

84. Raczkowska, M.; Wrzesińska-Kowal, J. Nierówności i ubóstwo ekonomiczne na obszarach wiejskich w Polsce. Rocz. Nauk. Ekon. Rol. I Rozw. Obsz. Wiej. 2018, 105, 7-17. [CrossRef]

85. Mejía Acosta, A.; Clark, J. Inclusive Local Governance for Poverty Reduction: A Review of Policies and Practices; Swiss Agency for Development and Cooperation, Institute of Development Studies: Bern, Switzerland, 2011.

86. Zaidi, A.; Makovec, M.; Fuchs, M.; Lipszyc, B.; Lelkes, O.; Rummel, M.; Marin, B.; de Vos, K. Poverty of Elderly People in EU25-First Report; European Centre for Social Welfare Policy and Research: Vienna, Austria, 2006.

87. Gasparini, L.; Alejo, J.; Haimovich, F.; Olivieri, S.; Tornarolli, L. Poverty among the Elderly in Latin America and the Caribbean; Center for Distributional, Labor and Social Studies at Universidad Nacional de La Plata: La Plata, Argentina, 2007.

88. Kubejko-Polańska, E. Managing the Functional Urban Development Through Implementation of the Silver Economy Concept-A Regional Perspective. In Knowledge-Economy_Society. Selected Problems of Dynamically Developing Areas of the Economy; Seweryn, R., Rojek, T., Eds.; Foundation of the Cracow University of Economics: Cracow, Poland, 2017; pp. 331-339.

89. Laperche, B.; Boutillier, S.; Djellal, F.; Ingham, M.; Liu, Z.; Picard, F.; Reboud, S.; Tanguy, C.; Uzunidis, D. Innovating for elderly people: The development of geront'innovations in the French silver economy. Technol. Anal. Strateg. Manag. 2019, 31, 462-476. [CrossRef]

90. Podgórniak-Krzykacz, A.; Przywojska, J.; Warwas, I. Silver economy as a response to demographic challenges in polish regions: Realistic strategy or Utopia? Innov. Eur. J. Soc. Sci. Res. 2020. [CrossRef]

91. Jedynak, T.; Maj-Waśniowska, K.; Mamcarczyk, M. The Challenges for Local Government Units in the Face of the Silver EconomyEvidence from Poland. In Proceedings of the Education Excellence and Innovation Management: A 2025 Vision to Sustain Economic Development during Global Challenges, 35 th International Business Information Management Association, Sevilla, Spain, 1-2 April 2020; pp. 16840-16853.

92. Kubejko-Polańska, E. Rzeszowski Obszar Funkcjonalny w obliczu wyzwań stawianych miastom i gminom przyjaznym starzeniu oraz rozwoju srebrnej gospodarki. In Teoria i Praktyka Rozwoju Obszarów Funkcjonalnych; Kudłacz, T., Brańka, P., Eds.; KPZK PAN CLXXIV: Warsaw, Poland, 2017; pp. 200-208.

93. Mei, W.-B.; Hsu, C.-Y.; Ou, S.-J. Research on the Evaluation Index System of the Construction of Communities Suitable for Aging by the Fuzzy Delphi Method. Environments 2020, 7, 92. [CrossRef]

94. Humphries, R.; Thorlby, R.; Holder, H.; Hall, P.; Charles, A. Social Care for Older People. Home Truths; The King's Fund: London, UK, 2016. 
95. Zeng, Q.; Wang, Q.; Zhang, L.; Xu, X. Comparison of the Measurement of Long-Term Care Costs between China and Other Countries: A Systematic Review of the Last Decade. Healthcare 2020, 8, 117. [CrossRef]

96. Lagergren, M.; Kurube, N.; Saito, Y. Future Costs of Long-term Care in Japan and Sweden. Int. J. Health Serv. $2018,48,1$. [CrossRef] 